\title{
Constraints on Budgeting and Development Plan Implementation in Nigeria: an Overview
}

By

\author{
Emmanuel O. Ojo ${ }^{1}$ (ph.d)
}

\begin{abstract}
After over five decades of planning and budgeting, no doubt, Nigeria is at a crossroad in terms of infrastructural development. Basic things of life which could make life abundant and tolerable are conspicuously lacking. So many reasons have been adduced for the stark reality; but the focus of this paper is an in-depth analysis of the variables which must have hampered the performances of several development plans cum annual budgets in achieving development goals. The paper infers that unless the identified lapses as discussed in this paper are taken care of the country may not be able to compete at even keel with her contemporaries visà-vis development indices.
\end{abstract}

Key words: Budget, Development Plan, Corruption, Economy, Gross Domestic Product (GDP).

\section{Introduction:}

Since 1960 when Nigeria got 'flag independence' and along with several other African states have since identified development as their main priority. They have come to understand the fact that the difference between them and the developed world is mainly that of the differential in levels of development (Ayoade, 1983:61). Yet, despite all pronouncements and relatively huge investments, Nigeria and several other African countries have achieved very little in improving capita welfare. Empirical data from Nigerian economy after decades of budgeting and development plan implementations is far from being cheering. Nigerians are far worse off now than they were fifty years ago (see, Ojo and Adebayo, 2012:14-30). Recently, the Federal Ministry of Health disclosed that the death toll from the scourge of cholera epidemic that ravaged some Northern

${ }^{1}$ Department of Political Science, Lagos State University, Nigeria. 
states: Borno, Bauchi and five other states had risen to 571 from 360 recorded earlier. The number of infected persons has also increased from 5,320 to 10,134 people, out of which Borno and Bauchi states recorded 2,617 and 2,417 cases respectively. The Health Ministry had earlier revealed that there had been more than 6,200 cholera cases since June 2010 with the disease detected in 12 of Nigeria's 36 states (see The Punch, 14 September, 2010).

Despite several billions of dollars in export revenues since the discovery of oil in the late 1950s, at least half of Nigerians still live in abject poverty without access to clean water. Literacy is below that of the Democratic Republic of Congo (see, Maier, 2000:xxi). Gross Domestic product (GDP), per person is lower now than it was before the beginning of the oil boom of the 1970s. To even return to the living standards of that time, the economy would have to grow by an unlikely 5 percent per year until 2010 (Ibid. p.xxi). With an estimated population size of 100 million (1999 estimate), the GDP (1998 estimate) is \$36 billion while estimated real growth rate (2000) is $2.7 \%$ per capital GDP (1999 estimate) is $\$ 300$ with an inflationary rate of $6.6 \%$ (2000 estimate) (see, Report on Nigeria in 2000:12 of 18). The value of the national currency, the Naira, has fallen from N2.00 to pound sterling in the early seventies to as much as N250.00 to a pound now. The foreign debt stands at about five billion US dollars in early 2010 (including the sum of 915 million dollars loan hastily approved by the National Assembly. Similarly, local debts too recorded a sharp increase from N1.7 trillion (about 10.02 billion dollars in 2006/2007 to about N3.2 trillion (20.0 billion dollars) as at December 2009 (cited in Ojo and Adebayo, 2012). The World Bank ranks Nigeria as the thirteenth poorest country in the world. The 1999 Human Development Index gives it a slightly better though still disheartening score $146^{\text {th }}$ out of 174 (Maier,2000:xxii for more on how the country has fallen, see Osaghae 1998). On comparative basis, the dilemma is more annoying when the country is compared with other countries like Malaysia, South Korea Singapore and Indonesia that are not as endowed in natural resources and were in the same situation as Nigeria in the 1960s. These countries have experienced marked industrialization with improved quality of life for the vast majority of their population since the 1990s when Nigeria cannot confidently say it is on the path to industrial growth (Aiyede, 2010:23-25).

It is imperative to note that the concomitant effect of poor planning and budgeting is lingering poverty. Nigeria's poverty conundrum has assumed a frightening dimension. In the words of Dr. Magnus Kpakol, Senior Special Assistant to the President and National Coordinator of National Poverty Eradication programme, in a public lecture entitled 'Poverty Solution: the role of Government in Poverty Eradication' declared that 'the number of poor Nigerians could be put at an estimated figure of 20 million...in 1980, the figure was 
28.1million, 1985, 46.3million, 1992, 42.7million, 1996, 65.6 million and 1999, 70.0 million, 2004, 54.4million' (see, National Life, September 13, 2008). He gave the statistical breakdown along the six regional levels to be '72.2\%in North-East, South East, 26.7\%, South-South, 31.5\%, South West 43.1\%, North Central 67.0\% and North West, 71.2\%' (Ibid.).

The question at this juncture is to ask: why the picture is so gloomy more so in view of the fact that since independence all levels of government have been budgeting and planning which is the basic thrust of this paper.

With this background, the rest of this paper is organized as follows: section two deals with the history of planning in Nigeria; section three dwells on conceptualization of budgeting and development plan to bring out what they connote. The final part of the chapter is an in-depth analysis of the major constraints on planning and budgeting in Nigeria. The paper however infers that the bane of Nigeria's under-development is not unconnected with the wide gap between intents and actual practices on the part of both public policy formulators and implementation machineries. The paper thus calls for a strong political will on the part of the state managers if the lots of an average Nigerian will be improved upon.

\section{History Of Development Plans}

Nigeria's development planning efforts date back to the end of the Second World War, when in 1945 the colonial office requested the local administration to submit a 10-year development plan to act as guide in the allocation of colonial development and welfare funds (Lambo, 1989:208). This resulted in the 10 year plan of development and welfare for Nigeria in 1946. It was supposed to cover the period 1946-1956. This ten-year plan was essentially an ad hoc list of selected projects without a common conceptual framework (Taiwo, 1995: 141). In 1950, however, it was realized that it was not feasible to chart development over a period as long as ten years in a country that was undergoing rapid structural changes. A decision was taken to break the interval into two five-year periods. A new plan for 1951-1956 was then formulated.

The next major effort to plan in Nigeria was in 1953 when the World Bank was invited to send an economic mission to Nigeria. The 1955-1960 economic programmes followed largely the recommendation of the Bank's report. These pre-independence plans were actually prepared by colonial government officials and hence they (the plans) failed to satisfy the important requirement of good planning - namely, the involvement of the people whose welfare the plan was supposed to cater for (Eyitayo, 1989:209). These early attempts at national development planning were not very successful. One of the reasons was that attempts at centralized planning gave way to regional uncoordinated planning 
when the country became a federation (Ayoade, 1983; Eyitayo, 1989 and Taiwo, 1995). Other possible reasons that may be adduced for the pre-independence plans not being very successful include: the absence of properly defined objectives relevant to the country's needs and inadequate administrative machinery to provide a high level capacity for plan implementation. In the same vein, O'Connell (1971:39-57) offered similar reasons why pre-independence developments failed to achieve their targets too.

Meanwhile, post-independence development plans have been efforts at expediting the processes of economic growth in the country. There are at least four notable ones. The first national development plan was that of 1962-1968. The second one was 1970-1974, the third one was 1975-1980 and the fourth national development plan was the 1981-1985. Each of these plans embodied the goals, strategies and formulae in the form of public investment programmes and socio-economic policies that will assist in accelerating the country's development process within a comprehensive framework. Analysis of each of the plans reveals that the 1962-68 plans was launched in June 1962 with the main objective of bringing about a rabid increase in the standard of living of Nigerians. The plan document envisaged a total investment programme of $£ 2,366 \mathrm{~m}$ for both the public and private sectors of the economy to bring about the desired objectives. The 1970-74 plan documents aimed at the increase in productivity with respect to agriculture, manufacturing industries, and the exploitation of petroleum. Total public sector investment was fixed at $\$ 3.349 \mathrm{~m}$. the third national development plan which was formally launched on March 29, 1975 projected an aggregate investment expenditure in the economy to be within the sphere of $£ 45.000 \mathrm{~m}$ in order that the objectives of establishing Nigeria firmly as a united strong, and selfreliant nation, full of opportunities for all citizens and a free and democratic society can be attained (Omitusa, 1985:32).

Afterwards, there are other development plans like the 1989-93 plan, 1996-98 National Rolling plan and 1999-2001 National Rolling Plan. It need be emphasized that if any development plan is to be described as being visionary and highly comprehensive, it was the Vision 2010 of Gen. Sani Abacha's administration. The Committee that worked on the plan was inaugurated on $27^{\text {th }}$ November, 1996. The committee comprised 248 members, including 25 foreign stakeholders resident in Nigeria, the rest were government appointed and elected representatives of the people. The committee's mandate set out a 14-item of reference, required it to develop a blue print that will transform the country and place it firmly on the route to becoming a developed nation by the year 2010. The Committee worked for ten months using the following methodology:

$>$ Plenary sessions, held in the form of 12 workshops, spread over the period; 
$>$ Sub-committees in particular problem areas;

$>57$ external workshops;

$>$ Specifically commissioned studies;

$>$ Consideration of 750 memoranda from the general public;

$>$ Presentations by guest speakers; and

$>$ Intensive brainstorming among committee members.

Arising from the result of this process, the Committee concluded that by 2010 , Nigeria would have transformed into a country which is "a united, industrious, caring and God-fearing democratic society, committed to making the basic needs of life affordable for everyone, and creating Africa's leading economy" (Vision 2010 Reports, 1997). This vision suffered same fate of lack of continuity like the preceding ones, most especially as a result of both political and governmental instability. The vision has been put into abeyance with the mysterious demise of Gen. Sani. The section on constraints delves much into the reasons why the vision was cumbered to avoid unwarranted recapitulation. The rest of the paper is organized into two major sections. First, conceptual clarification and an in-depth analysis of the major hurdles to development plan implementations. We now proceed to conceptualize the two key terms made use of in this paper, that is, budget and development plan.

\section{Conceptual clarification}

\section{(a) Budget}

A budget is simply the statement of expected income and expenditure over a time period, usually a year of the government. Governments at all levels do envisage how much they are likely to generate from all source available to them. At the same time, they visualize what the expenditure will be. The income side of a budget normally does include loans sourced both internally and externally. In essence, budget has become the means by which governments achieve their objectives. The major advantage of budgeting is to guarantee orderly development. Governance without sound budgeting will definitely result into haphazard development if there is development at all. It is important to note that a budget has two major sides. First recurrent expenditure, which is the cost of the day-to -day administration of the state and second capital expenditure which means the money earmarked to execute capital projects.

Beyond the state, budgeting concerns virtually everybody. Both individuals and organizations do budget to get themselves financially organized. This will go a long way to prevent unwarranted impromptu purchases. Without a budget government expenditure will be based on the whims and caprices of the rulers with all its accompanying problems such as lack of accountability. 
In the extant literature on budgeting generally, there are a number of budgeting techniques, the major ones are (i) incremental technique; (ii) zerobased technique; (iii) performance technique and (iv) planning, programming and budgeting systems techniques (PPBS), the significance of budgeting to the state is better underscored by the fact that a whole department or ministry is normally created to take care of the assignment.

\section{(B) Planning}

Like budgeting, planning is crucial too to states, individuals and organizations. The popular saying is "he who fail to plan, plans to fail". Without good planning, development which is assumed to be the ultimate goal of all becomes a mirage. The primary reason for planning is to take care of the future. Thus, planning is deciding in advance what to do, how to do it, when to do it, who is to do it, why do it, and how much resources are to be used.

Planning requires both skill and innovation than budgeting because the time period that development plans normally do take care of is much longer than budgeting that is barely twelve calendar months. Put differently, planning is anticipation of the future based on the present. The figure 1 below shows what a good plan is and how to achieve it is.

Be that as it is, a good development plan must possess the following characteristics:

(1) Be specific and clearly stated for easy understanding.

(2) Possess measurable or verifiable achievement.

(3) Realistic and consistent.

(4) Possess specific period of achievement.

(5) Include intermediate targets or goals that will facilitate the attainment of the major objectives.

(6) Modern and up-to-date

(7) Can be ranked according to relative importance and form a network.

(8) Possess desired results and events, including goals that must be interconnected and mutually supportive.

(9) Carry the citizenry along to avert legitimacy crisis

(10) Be spatially fair in a plural society. 
Fig. 1

Plans as the foundation of Management

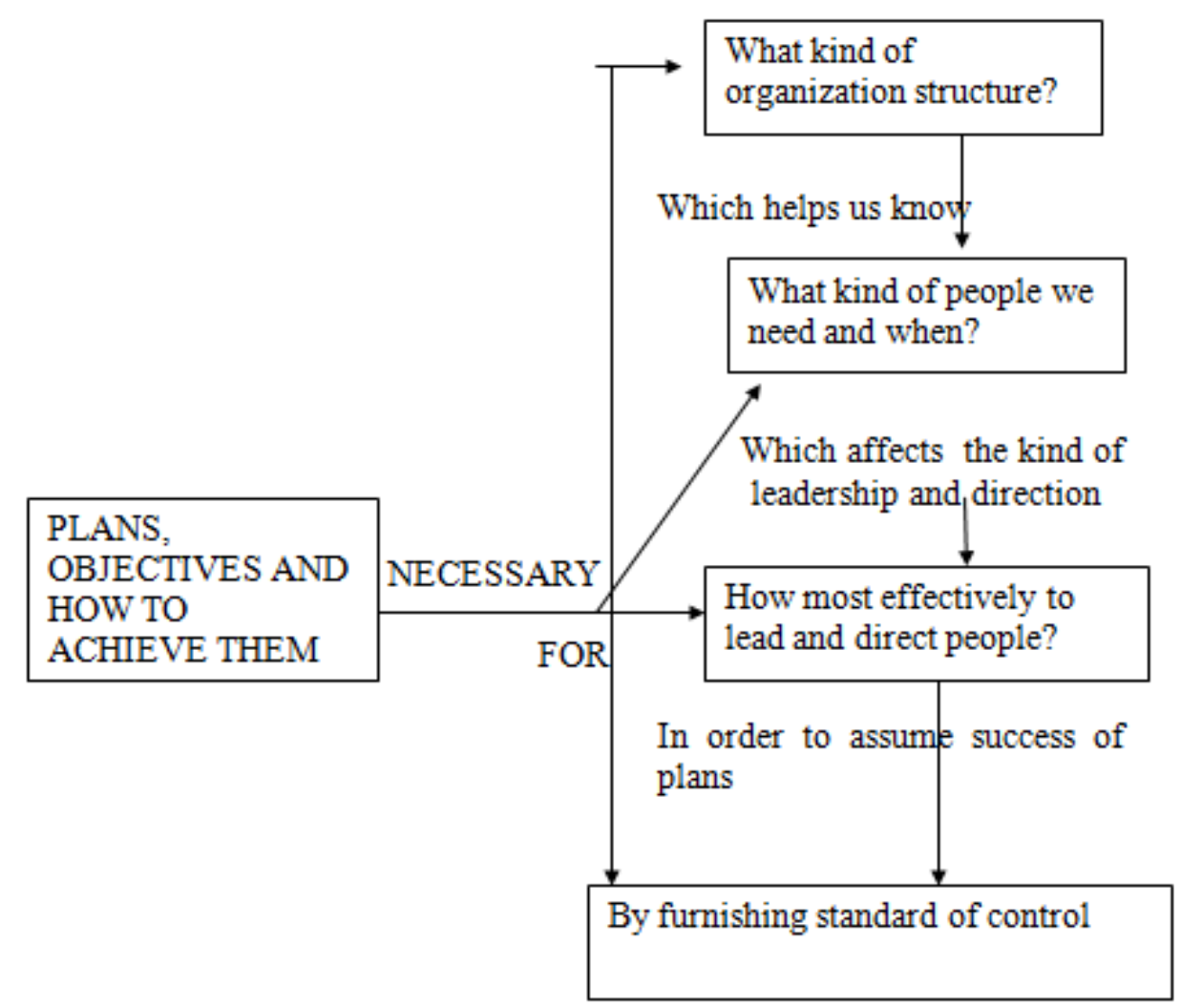

Source: Harold Koontz and Cyril O’Donnel, Management: A system and Contingency Analysis of Managerial Function, 6 ${ }^{\text {th }}$ Edition, p. 132

\section{Major Constraints}

This section, which form the lives of this chapter, examines the problems of development plan and budgeting implementations highlighting why they have nor been very successful in Nigeria. To start with, with due respect to the plancontents, it has been observed that most of the plans were over-ambitions and unattainable, considering the resources (human and natural) that abide in the country. The prevailing technological level has always be relegated to the background and ranked unimportant in the planning process so that it becomes very difficult when operational bottlenecks begin to creep in as work progresses. Whereas, any budgeting technique or development plan that falls to appreciate this fact cannot succeed.

Second, weak database is a major hindrance too. In Nigeria and several other third world countries, paucity of data is prevalent. A country that has never been able to conduct a scientifically proven and generally accepted population census can never be a good planner for the future. In most cases forecasts are 
done based on grossly inadequate information, thereby, resulting into distorted growth. The problem really in Nigerian context is multi-faceted, for instance, the level of technological development is hindering data gathering, processing and storage. Likewise the orientations, behaviour, general attitude cum religious and cultural disposition of Nigerians do go a long way to making realizing accurate data difficult. For instance people supply wrong information on economic data to evade tax. An average Yoruba man never discloses the number of children he has. It is considered a taboo while Moslems bury their dead almost immediately without bordering about death certificate that helps calculate death rate. To worsen the situation, politicians too do inflate figures or deflate same to suit their purposes for political manipulation to get political favour for their community. These are serious hindrances to accurate data. Recently, the federal government mooted the idea of resuscitating national identity card project. Surprisingly, the northern potentates vehemently opposed the project for purely political reasons. The believe in political circles is that this may break the jinx of Northern claim to larger population size, which it has been using to get more representations and other accompanying advantages development-wise. Above all, civil servants in charge of data gathering need to be given re-orientation on the significance of data. The reason for this is most cases are that available data are far from being up-dated.

Thirdly, there are a number of political constraints on public policy implementations. First, there must be political will-to-rule and plan. James O'Connell (1971:47) puts it succinctly that the biggest single problem in political leadership is to find in new states whose political psychology is oriented to development. Traditional attitude in which power was geared especially to order and to adjudication slip gently into new constitutional and administrative structures and halt before developmental decisions. Hesitation before developmental decisions is aggravated by the time-consuming demands of politicking, by an unwillingness to resolve converging and competitive claims to benefits among the ruling groups, and by uneasiness in face of radical innovation often urged by technicians who are less exposed politically than the politicians, not always wholly trusted by them, and too obviously more rational in their approach. Even military rulers seldom escape the carry-over of these more static traditional attitudes of power - and a reluctance to use power developmentally may be even more pronounced among soldiers unless the latter are deeply convinced that they have a popular mandate to rule.

Secondly, in a plural and deeply divided federal society like Nigeria planners are faced with a great challenge of spatial development. All the component parts of the federation want attention. Where developmental projects are skewed in favour of a region than others the marginalized group(s) becomes 
alienated. In that wise, development plan do not wear national outlook. It is for this reason that ethnic balancing becomes imperative to prevent the dominance of a few ethnic groups or religious groups. It will be recalled that religious bias proved another form of poor benefit distribution in the country in the second republic. Countrywide, Muslims obtained about $70 \%$ of all executive and board positions (Ayoade, 1987:134).

However, political events have proved the futility of this kind of approach in the sense that public makers have become in managing Nigeria's diversity with the establishment of Federal Character Commission (FCC) to take care of the shortcomings inherent in the application of federal character principle in Nigeria (see, Ojo, 2002:37-52). The concomitant effect of poor ethnic balancing vis-à-vis development plan implementation will be lack of trust and solidarity in the political community; whereas basic affinity between the state and the citizenry is of paramount importance if the citizens will be willing to make sacrifices without necessarily counting the cost.

Thirdly, because of lack of managerial effectiveness in developing countries, (See, Stahl, 1979:1-5), the best efforts to secure growth that is commensurate with aspirations, especially in Nigeria is usually frustrated. This boils down to the quality of education and training received by the citizens. In other words, a country that is seriously short of the trained manpower and other resources essential to keep any nation viable, and equally critically dependent, above all, in the character and capacity of its public bureaucracy will definitely find it difficult to attain whatever future goal it may set for itself. In the same vein, it is one thing to prepare budget annually and it is another for such budgets to be prepared for the political executives by the required skilled and experienced bureaucrats. What should usually be at the back of the minds of experts is the fact that public sector budget is an instrument for several ends (Pinto, 1981:27-30).

For effective development plan and budgeting implementations, the principle of social equality needs to be adhered strictly to. Presently, developmental efforts are highly concentrated in the urban centres, thus, marginalizing the rural dwellers. It needs be emphasized that an all-round development strategy that takes care of all is more desirable. The snag however is that even when development plans and budgets are fair - in terms of social equality - operators of the system do divert resources meant for rural development to take more care of the urban (see, Obadan and Ogiogi, 1994).

Furthermore, budget indiscipline is a factor that needs to be emphasized too. The chief objective of drawing up budget is to achieve national spending through careful consideration of priorities and options. Though, factors like inflation may affect budget, but unnecessary flexibility is a problem too. This has always been a reason for financial recklessness. For instance, Nigeria planned to 
move her capital away from Lagos to Abuja by the year 2000, while construction work commenced in 1981, General Ibrahim Babagida for spurious security reasons moved the federal capital in December 1991 after the abortive Orkar Coup (Ojo, 1998:38) not minding the financial implications for the country and worse still, distortion of the plan for moving the federal capital. Such financial recklessness has contributed in no small measure to the present economic predicament of the country.

Finally, corruption which is "acts that is intentionally dishonest" (Lodge, 1998:157-187) or "a method of exploitation by which a constituent part of the public sphere is exploited as if it were part of the market sphere" (Klaveren, 1970:38) is indeed pervasive in Nigeria. It is amazing that the magnitude of corruption in Nigeria totals 10 percent of the country's Gross Domestic Product (GDP), (See, The Economist 21st August, 1996). In a polity like this development becomes 'arrested'. Indeed, besides the institutional and structural innovations that make for a system of good governance, a corruption free sustainable development requires a "moral determination" (Diviredi, 1997:609-709). Recognition of that moral determination in governance marks the direction in which those who govern must channel their efforts toward the common good if they are to justly serve the society. That direction calls for individual moral responsibility and accountability sacrifice, compassion, justice and an honest effort to achieve the common good. In the word of R.B. Jain (2001:7), "ultimately, it is the moral determination which provides the foundation for governance towards a corruption free sustainable development and democratic consolidation". Transparency International (TI) based in Germany has detailed the effect of corruption to include displacement of priorities, acceptance of wrong projects or the choice of inappropriate method of execution, putting wrong people in position of trust and responsibility, incurring and tolerating unreasonable levels of expenditure among others. Certainly each or a combination of these distortions will have adverse consequences on budget implementation and attainment of development plan goals (cited in Ojo, 2001:18; 2002:133).

\section{Concluding Remarks}

This paper has extensively discussed the major constraints to both budgeting and development plan implementations. Having highlighted the problems, we now put forward the following policy recommendations:

(1) The development plans should be such that they are feasible within the stipulated time period. Adequate cost-benefit analysis should be done to ascertain the need for a particular project within the plan document and also with the strategies. 
(2) The administrative bureaucracy relating to certain desirable projects should be minimized.

(3) Government should attempt to conduct a reliable population census to enable us know how many people we are actually planning for, and

(4) Finally, institutional constraints and human factors of corruption and mismanagement should be minimized through stringent penalty for offenders.

If the above suggestions are affected, future development plans and budgeting will be more successful than both the present and past ones.

\section{References}

Aiyede, 'Remi, (2010), 'Nigeria at 50: Development Performance in Comparative Perspective', Nigerian Tribune, Ibadan, (May 30).

Ayoade, J.A.A. (1983), "The administration of development plans in Africa: A Comparative Perspective:, The Nigerian Journal of Economic and Social Studies, Vol. 25 No. 1 (March).

Ayoade, J.A.A (1987), "Ethnic Management in the 1979 Nigerian Constitution", Canadian Review of Studies in Nationalism, Vol. XIV No. 1 (Spring).

Duvivedi, O.P. (1997), "Moral Dimensions of Statecraft", Canadian Journal of Political Science, Vol. 20 No. 4

Jain, R.B. (2001)“Toward a Corruption Free Sustainable Development: Emerging Paradigms of Good Government in the $21^{\text {st }}$ Century", being a keynote address prepared for the IPSA RC4 Mid-term Conference, held at Abuja, Nigeria, Between 15-18 October.

Lambo, Eyitayo, (1989), "Perspective Planning in Nigeria with specific Reference to the Social (Health) sector", The Nigerian Journal of Economic and Social Studies, Vol. 31, Nos, 1,2 \& 3.

Lodge, T. (1998), "Political Corruption in South Africa", African Affairs, Vol. 97.

Maier, Karl, (2000), This House Has Fallen: Nigeria in Crisis, Penguin Books, England.

O’Connell, James, (1971), "Political Constraints on Planning: Nigeria As a case study in the developing World", Nigeria Journal of Economic and Social Science, Vol. 13.

Obadan, Mike I., and Ogiogi, Gene, O., (1994), Planning and Budgeting in Nigeria: Institutional and Policy Reform, NCEMA Publication, Ibadan.

Ojo, E.O. (2002), "An Appraisal of the Principle and Practice of Federal Character in Nigeria", Political Science Review, Vol. 2 No. 
Ojo.E.O. [1998], “The new Federal Capital Territory as Integrative Mechanism in Nigeria, Indian Journal of Politics, Vol, XXXII Vols, 1 \& 2

Ojo, E. O., (2001), "The Phenomenon of Corruption and the Challenge of Democratic Consolidation in Nigeria: A Prognosis", being the text of a paper presented to an International Conference on "Towards a Corruption free Sustainable Development: Challenge for Good Governance and Prosperity in the 21st Century". Organized by International Political Science Association (IPSA), held at Sheraton Hotels, Abuja, Nigeria between 15 th -17 th October.

Ojo, E. O., (2002), "The Nigeria Police Force, Phenomenon of Corruption and Effective Policing in a Democratic Setting: An Overview", Journal of Law and Social Sciences, Vol. 2 No. 1 (May).

Ojo, E.O., and Adebayo P. F.,(1012), 'Living Without the State: A Rear View Mirror of Nigeria's 40 Years of Independence', African Social Science Review, vol. 5 No. 1 (Spring).

Omitusa, Solomon (1985), "Planning and Plan Implementation in Developing Economies: The Nigerian Experience", The Economic Insight, An Annual Journal of the Nigerian Economics Students' Association (NESA), OAU, Ife.

Osaghae, E.E. (1998), Nigeria Since Independence: Crippled Giant, C. Hurst \& Co., London.

Pinto, Rogerio F., (1981), "Public Sector Budgeting: A Public Economics and a Public Administration Approach", International Review of Administrative Science, Vol. XLVII No. 1

Political Corruption: Readings in Comparative Analysis, New York, Holt Reinhart and Winston.

Reports on Nigeria in 2000, (2001), Whitney M. Young (Jr.), Information Resources Centre, Public Affair Section, Consulate General of the United State of America, Lagos, Nigeria.

Stahi, O. Glenn, (1979), "Managerial, Effectiveness in Developing Countries", International Review of Administrative Sciences, Vol. XLV No. 1.

Taiwo, I.O. (1995), "A Review of Planning and Budgeting Activities in Nigeria”, in H.O. Danmole et. Al., (eds.), Contemporary Issues in Nigeria Affairs, Sunad Publishers, Ibadan The Economist, (London).

Federal Government of Nigeria, Vision 2010 Reports (1997), Government Printers Abuja. 